\title{
INTERNALISASI NILAI-NILAI KEISLAMAN PADA ANAK-ANAK PARA MUALLAF
}

(Studi Kasus Pondok Pesantren Umar Bin Abdul Azis di Dusun Tolonggeru Kecamatan Madapangga Kabupaten Bima Tahun 2016)

\author{
Hermawansyah \\ dan \\ Suryani \\ STIT Sunan Giri Bima \\ hermawansyahbima@yahoo.co.id
}

\begin{abstract}
Abstrak: This research purpose to describe internalization of Islamic values to muallaf children The Research focus are internalization process, strategy, enabling and inhibiting factors internalization of Islamic values. The main problem is increasing religious conference in tolonggeru village, then more children are mualaf. But with the lack of understanding of Islam background their parents, so that the difficulties for parents provide an understanding of Islam for theirs. Presence The pondok pesantren Umar Bin Abdul Aziz, assist in the internalization of Islamic values to mualaf children. This research uses qualitative descriptive method. The research subject is headmaster of Islamic boarding school, teacher, people and religious figure. data collection techniques using methods of observation, interviews and documentation. data analysis using the phenomenology of interpretive approach, triangulation, and deductive. The results of this research include the first; introduction of tauhid, comprehension syaria'ah ahlaq, aqidah, and realizing value of ilahiah and insaniyah. The second; exemplary strategy, exercise and conditioning, and advisors. Generally, researcher concludes that internalization the values of Islamic by pondok pesantren Umar bin Abdul Azis, to give a positive value for mualaf and positive value for majority people, with socialization style of Islamic values do without claim of the people and always fostering harmony.
\end{abstract}

Keywords: Internalization, Islamic values, muallaf children

\section{Pendahuluan}

Nilai-nilai Keislaman pada akhir-akhir ini telah memudar dipicu oleh gaya kehidupan zaman yang semakin berkembang dan diperlukan kekuatan untuk merekonstruksi kembali menjadi suatu komitmen bersama, Bahwa Nilai-nilai ini tidak begitu saja dapat tumbuh dalam diri tanpa suatu tekad yang kuat. Tentu ditata dan di lihat kembali Agar menjadi cerminan ditengah kemajemukan terutama 
keberagaman agama, dari keberagaman agama di dunia ini menghasilkan suatu venomena yang unik yaitu konfresi agama atau perpindahan kepemeluk agama dari agama yang satu ke agama yang lainnya, Max Heirich sebagaimana yang di kutip oleh Ramayulis mengatakan bahwa Konvrensi agama adalah suatu tindakan dimana seseorang masuk atau berpindah ke suatu sistim kepercayaan atau perilaku yang berlawanan dengan kepercayaan sebelumnya. ${ }^{1}$ Tentu dengan hal ini nilai-nilai keislaman yang memadai harus memadati hati pikiran dan perilaku seseorang yang melakukan konfersi agama.

Fenomena perpindahan agama dari agama yang satu ke agama yang lain bukanlah hal yang baru namun di dalam al-Qur'anpun telah di jelaskan bahwa konvrensi agama telas terjadi sejak Zaman Nabi Ibrahim as Sebagaimana Firman Allah dalam QS. Al-An'am: 76-78.

Artinya: Ketika malam Telah gelap, dia melihat sebuab bintang (lalu) dia berkata: "Inilah Tuhanku", tetapi tatkala bintang itu tenggelam dia berkata: "Saya tidak suka kepada yang tenggelam." Kemudian tatkeala dia melibat bulan terbit dia berkata: "Inilab Tubanku". tetapi setelah bulan itu terbenam, dia berkata: "Sesunggubnya jika Tubanku tidak memberi petunjuk kepadaku, Pastilah Aku termasuk orang yang sesat." Kemudian tatkala ia melihat matahari terbit, dia berkata: "Inilah Tubanku, Ini yang lebih besar". Maka tatkala matahari itu terbenam, dia berkata: "Hai kaumku, Sesunggubnya Aku berlepas diri dari apa yang kamu persekutukan.

Internalisasi nilai-nilai keyakinan dalam keislaman merupakan dakwah tauhid sebagai misi kerasulan yang mesti dilanjutkan untuk memperkuat iman para muallaf. Maka untuk melanjutkan misi dakwah tersebut bukan terhenti pada orang-orang muallaf akan tetapi perlu melindungi generasi atau anak-anak muallaf kearah keyakinan Islam yang kokoh

Karena itu, perlunya menjaga akidah para muallaf. Agar mampu mengembangkan ketajaman intelektual dan integritas diri sebagai peribadi yang memiliki karakter kuat, ${ }^{2}$ atas keyakinannya, atau Diantara hal yang dilakukan adalah membimbing atau menginternalisasikan nilai-nilai keislaman pada anak-anak para muallaf melalui pondok-pondok pesatren yang memiliki ciri khas lingkungan yang

${ }^{1}$ Ramayulis, Psikologi Agama ( Jakarta: Kalam Mulia, 2002), 67

2 Doni Koesoema A, Pendidikan Karakter (Jakarta: PT. Grasindo, 2007),115 
beragamais dan berakhlak mulia, ketika orang tua telah melakukan konversi agama maka tantangan terbesar itu terletak pada pembinaan agama anak, keseriusan dalam membina pemhamaman anak-anak dari para muallaf mesti berada pada lingkuangan yang mampu mengkondisikan aktifitas keseharian anak-anak para muallaf kearah yang agamais mengingat pemahaman orang tua yang baru saja menyakini agama baru, tentu tidak memiliki pengetahuan agama baru yang di yanininya untuk di internalisasikan pada seorang anak, sedangkan kewajiban orang tua dan pendidikan bagi anak berada pada lingkuangan keluarganya. Dengan demikian pergerakan untuk memberikan bimbingan tentang nilai-nilai Keislaman pada anak-anak muallaf sangat tepat dan perlu.

Sebab Muallaf adalah orang yang masuk kedalam Islam, yang pada awalnya dia beragama lain karena suatu hidayah atau petunjuk atau alasan lain dia memutuskan untuk meyakini Islam dan berpindah keyakinan ke agama Islam. Hasby Ash Shiddieqy berpendapat bahwa muallaf ialah mereka yang perlu dilunakan hatinya, di tarik simpatinya kepada Islam atau mereka yang di tetapkan hatinya di dalam Islam. $^{3}$

Untuk itu Perpindahan agama merupakan proses perubahan sosial serta perubahan pandangan dalam kehidupan seseorang. Berangkat dari hal ini tentu pengetahuan agama atau keyakinan barunya sangatlah minim sebagai bekal untuk mendidik anak-anaknya di dalam rumah atau lingkungan yang masih berbaur dengan agama sebelumnya. Maka sangatlah tepat pondok pesantren hadir sebagai wadah untuk mendidik atau menginternalisasikan nilai-nilai keagamaan pada anak-anak muallaf, sehingga dapat merubah budaya lingkungannya menjadi lingkuangan yang baik untuk para anak-anak muallaf.

Internalisasi nilai-nilai keislaman yang di ajarkan pada pondok pesatren Umar Bin Abdul Azis meliputi, pendidikan Islam, dakwah, pengembangan kemasyarakatan dan pendidikan lainnya sebagai pertalian sunnah itu perlu diketahui untuk kemudian diterapkan dengan sangat hati-hati. ${ }^{4}$ Yang mana dalam pesantren para santrinya disiapkan untuk dapat berbaur dalam pergaulan di masyarakat dengan adab yang sesuai dengan moralitas dalam agama Islam. Hal ini begitu diperhatikan karena

${ }^{3}$ Hasby Ash Shiddieqy, Pedoman zakat (Jakarta PT. Bulan Bintang, 1984),18

${ }^{4}$ Muhammad Husain Haekal, Umar bin Khattab (Bogor : Litera Antar Nusa, 2011), 690 
lingkungan pondok pesantren berada dalam lingkungan masyarakat yang luas dan yang menilai baik buruknya dari sebuah pesantren tersebut adalah bagaiman adab dari santri jebolan pondok pesantren tersebut dengan masyarakat sekitar terutama di lingkungan keberagaman umat. Di dalam pondok pesantren ini peraturannya dikuasai penuh oleh sang ustaznya atau pengasuh pondok. Jadi para santri dibimbing dengan jalan yang sama.

Didalam mempersiapkan genarasi atau anak-anak Islami tentulah dalam pondok pesantren merupakan tempat yang tepat dan aman untuk mendidik baik mendidik akhlaknya maupun perilakunya sehingga dengan kebiasaan perilaku dalam lingkungan pondok pesantrenlah yang membentuk perilaku anak didik seuntuhnya untuk mengimbangi keadaan lingkungan masyarakat yang tak terdidik lewat perilaku dan nuansa Islami.

Pendapat di atas memberikan gambaran yang tepat jika pembelajaran pertama bagi anak adalah oleh orang tua, lingkungan dan masyarakat, maka konsekwensi perkembangan anak didik tersebut tentu pada pemahaman agama dan cara didik orang tua yang berada di lingkungan sekitarnya. Maka di sini penulis mengkaji secara mendalam terkait dengan keterbatasan ilmu agama yang dimiliki oleh orang tua yang muallaf di Dusun Tolonggeru.

Penulis menelusuri dari beberapa informasi di masyarakat Tolonggeru, dusun tolonggeru merupakan dusun yang berawal dari agama mayoritas yang hampir mencapai $99 \%$. Sejauh ini dengan adanya dakwah Islamisasi oleh lewat pernikahan dan dakwah para pendatang, sehingga sekarang pemeluk Islam tolonggeru mencapai $40 \%$ maka kristen dan katolik masih 60\%, keberagaman yang dimiliki Desa Tolonggeru memang sangatlah unik bahkan dalam satu rumpun keluarga masih memeluk keragaman agama tanpa ada masalah. Juga, sangat kuat membangun keharmonisan sesama yang begitu nyaman, aman dan damai dalam kehidupan sosial bermasyarakatnya.

Maka penulis menilai untuk lingkungan Dusun Tolonggeru sangatlah tidak kondusif untuk anak-anak para muallaf karena perilaku bergaulnya masih terlihat cara dan perilaku agama sebelumnya terutama kebiasaan tidak melaksanakan shalat ketika masuk waktu dan juga lontaran kata-katanya yang masih menggunakan kalimat yang tidak searah dengan ajaran Islam, disebabkan oleh keterbatasan ilmu agama 
yang dimiliki oleh orang tua sebagai guru atau pendidik dalam rumah, dan pergaulan di lingkungan anak-anak masih ke arah non nilai-nilai keislaman dan masih melekat paham dan cara yang bercampur aduk dengan agama sebelumnya yang tidak sepaham dengan ajaran Islam, ini semua disebabkan oleh keterbatasan nilai-nilai keislaman yang diajarkan, maka dari itu, pondok pesatren sangatlah penting untuk menginternalisasi nilai-nilai keislaman pada anak-anak muallaf melalui pembelajaran keislaman yang intens dengan melakukan syari'at-syari'at Islam guna menyebarkan dan menyiarkan agama Islam ${ }^{5}$ yang berpedoman pada al-qur'an dan al-hadits, maka sebagai sebuah agama, islam berkembang melalui dua macam struktur, yaitu strutur keyakinan dan struktur peribadatan. ${ }^{6}$

Dari beberapa landasan permasalahan yang di ungkapkan di atas maka penulis terdorong untuk meneliti tentang, "Internalisasi Nilai-Nilai Keislaman Pada Anak-Anak Para Muallaf (Studi Kasus Pondok Pesantren Umar Bin Abdul Azis di Dusun Tolonggeru Kecamatan Madapangga Kabupaten Bima Tahun 2016)”.

\section{HASIL DAN PEMBAHASAN}

Penelitian ini berhasil mengkaji tiga permasalahan utama yaitu; Pertama; Proses internalisasi Nilai-Nilai Keislaman. Kedua; Strategi internalisasi Nilai-Nilai Keislaman. Ketiga; Faktor pendukung dan penghambat.

\section{Pertama: Proses Internalisasi Nilai-Nilai Keislaman}

Internalisasi nilai-nilai keislaman atau umumnya pengajaran agama dapat dipandang sebagai suatu usaha mengubah tingkah laku anak dengan menggunakan bahan atau materi dan nilai-nilai yang terkandung didalamnya. Perubahan tingkah laku anak itu semua tergantung dari pengajaran yang telah didapatnya. Ada beberapa pokok pelaksanaan dalam proses internalisasikan nilai-nilai keislaman pada anak-anak para Muallaf, berkaitan dengan keterbatasan pemahaman agama bagi orang tua yang melakukan konvrensi agama namun tidak dapat mendidik secara langsung anakanaknya di dalam lingkugan rumah sehingga pondok pesantren Umar bin Abdul Azis memiliki peran penting untuk meningkatkan tingkat religiusitas terhadap anak-anak para muallaf tersebut dengan berbagai macam program di dalamnya.

\footnotetext{
5 Suyoto, Pondok Pesantren Dalam Pendidikan Nasional. Diedit oleh M. Dawan Raharjo,Pesantren dan Pembaharuan (Jakarta: LP3ES, 1988), 71

${ }^{6}$ Doni Koesoema A, Pendidikan Karakter.,112
} 
Sebagaimana Ungkapan Ustadz Nehrun Lc, MA, bahawa proses internalisasi nilai-nilai keislaman yaitu dengan beberapa tahap, Pertama, bagaimana memperkuatkan keyakinan anak-anak para muallaf terhadap Allah yakni lebih memperkuat pada ketauhidan. Kedua, Syari'ah. Kempat, Nilai-nilai Aqidah dan Kelima Akhlak, secara sismatis anak-anak di ajarakan Lima aspek nilai tersebut. ${ }^{7}$ Selain itu, juga di tanamkan sumber nilai yang berlaku dalam pranata kehiduapan manusia yaitu nilai nilai Ilaihiyah dan nilai insaniyah.

\section{Tahap pertama: Mengenalkan Tauhid}

Tauhid merupakan landasan Islam yang paling penting. Apabila seseorang benar tauhidnya, maka dia akan mendapatkan keselamatan di dunia dan akhirat. Sebaliknya, tanpa tauhid, dia pasti terjatuh ke dalam kesyirikan dan akan menemui kecelakaan di dunia serta kekekalan di dalam azab neraka. Maka proses yang utama terhadap internalisasi keislaman pada anak-anak para muallaf yaitu tentang ketauhidan.

"Seperti yang diungkapkan oleh Ustaz Syarif yaitu, tauhid sangat peting ditanamkan pada anak-anak para muallaf sebagai pemahaman dasar terhadap pemahaman lain tentang Islam, seperti memperlihatkan mereka tanda-tanda kebesaran Allah, Misalnya tentang matahari, bulan, bintang, malam, dan siang yang selalu silih berganti, itu karena kekuasaan Allah, Kemudian ditanyakan tentang siapa yang mengendalikan matahari, Siapa yang mengatur bulan, Siapa yang mengendalikan malam Siapa yang mengatur siang tentu Allah yang mengatur, maka proses seperti inilah yangh di lakukan selama memberikan pemahaman tauhid terhadap anak-anak"

Sejalan dengan yang di ungkapkan oleh Ustaz Efendi bahwasan proses penanaman nilai Tahuid yaitu mengenalkan Tuhan yang Esa dan tiada duanya, yaitu dengan Fokus menyembah dan beribadah kepada Allah semata, maka di kenalkan kepada anak-anak tersebut bagaimana cara beribadah dan tempat ibadah yang menurut nilai-nilai keislaman dan kesucian bagi Allah. ${ }^{9}$.

Terkait dari hal tersebut bahwasannya penanaman tauhid merupakan tingkatan proses yang paling utama ditanamkan kepada anak-anak para muallaf dalam

\footnotetext{
${ }^{7}$ Nehrun, (Pembina) Wawancara Tanggal 20 Oktober 2016

${ }^{8}$ Syarif (Pembina) wawancara tanggal 22 Oktober 2016

${ }^{9}$ Efendy (Pimpinan ponpes) wawancara tanggal, 18 oktober 2016
} 
memperkokoh keisalamannya. Sebab, ketika manusia mampu mengenal tuhannya maka dengan sendirinya akan mampu mengenal segala kondisi kehidupan dalam menjalankan keislamannya.

\section{Tahap Kedua: Penanaman hukum Syari'ah}

Penanaman syari'ah merupakan panduan atau jalan untuk mengenal pada hukum-hukum Islam, dalam kehidupan Islam telah ditentukan garis langkah untuk menjalani kehidupan Islam yang lebih baik dan benar yaitu tidak keluar pada bingkai Al-Qur'an dan Sunnah sebagai hukum syariah yang ditetapkan.

Sesuai dengan yanag di ungkapkan oleh Pak Muhtar bahwa, sebuah kapal tanpa nahkoda maka akan terombang ambing, namun nahkoda tanpa peta maka akan terdampar artinya Islam tanpa ada hukum syari'ahnya maka tidak akan benar dan tak memiliki tujuan, demikian juga anak-anak para muallaf, ketika tauhid telah ditanamkan tanpa ada hukum yang jelas dipedomani maka tujuan keislamannya pun akan hanyut terbawa arus pemahaman yang tidak jelas. Sehingga proses yang di lakukan yaitu dengan mempbrikan pelajaran tentang syariah dan pengajian-pengajian tentang keislaman ${ }^{10}$

Sebagaimana proses pengenalan hukum syariah ini yang di sampaikan oleh Ustaz Nehrun adalah dengan memperkenalkan bagaimana hubungan hamba dengan Allah, hubungan sesam manuasia, kemudian bagaiamana cara beribadah, cara bersuci, , dan cara hidup di lingkungan sosial beragama. ${ }^{11}$

Hasil dari pendapat yang di ungkapkan di atas memberikan gambaran yang sangat jelas bahwa setiap muslim sangat perlu menanamkan nilai-nilai syari'ah sebagai langkah dalam melakukan segala aktifitas hidup sesuai dengan tunmtutan Al-Qur'anj dan Sunnah.

\section{Tahap Ketiga: Penanaman Nilai Aqidah.}

Nilai aqidah merupakan nilai yang di internalisasikan sebuah keyaninan kepada Allah. Sebagaimana yang di ungkapan oleh Ustadz Syarif bahwa di lingkungan pondok pesantren berawal dari mengenal animisme dan dinamisme dan hal itu selalu dilaksanakan di hadapan anak-anaknya bagi orang tua, sebelumnya dusun Tolonggeru merupakan dusun yang memiliki keberagaman yang melaksanakan multi kepercayaan,

${ }^{10}$ Muhtar ( Pembina) Wawancara tanggal, 19 Oktober 2016

${ }^{11}$ Nehrun, (Pembina) Wawancara Tanggal 20 Oktober 2016 
masyarakat dusun Tolonggeru yang mayoritas kristen juga melaksanakan kepercayaan animisme atau dinamisme yang biasa disebut dengan kepercayaan pada budaya ncubi. Sehingga penanaman nilai kepercayaan dan keyakinan kepada Allah terhadap anakanak para muallaf sangat perlu di berikan. ${ }^{12}$

Lebih lanjut Pak Edy Muliadin mengungkapkan bahwa Proses pengenalan terhadap Nilai Aqidah selalau di lakukan dengan membiasakan menghafal tentang rukun Iman, dan rukun Islam, untuk memberikan keyakinan kepada Allah. Mengigatkan terhadap anak-anak tentang rukun iman, rukun Islam dan sebagainnya di lakukan evaluasi melalui setiap kegiatan keislaman seperti ramadhan ceria dan sebagainnya pada bulan brmadhan, dan hal ini di lakukan dengan rutin untuk mengefaluasi pemahamannya anak-anak para bmullaf, semua ini di lakukan agar selalu terjaga dalam sanubari anak-anak para muallaf di dusun Tolonggeru yang akan menjadi generasi islam kedepannya. ${ }^{13}$

Dari hasi uraian di atas memberikan jawaban bahwa anak-anak di tanamkan keimanan terhadap tuhannya bahwa sudah tida ada tuahan lain yanag patut di sembah selain Allah, juga tidak ada kekuasaan lain yang di yakini selain allah, maka dengan pemahaman tersebut anak-anak paham tentang kebesaran Allah.

\section{Tahap Ketiga: Penanaman Nilai Akhlaq}

Sedangkan nilai Akhlaq lebih pada proses penanaman perilaku sebagaimana yang di kemukakan oleh Ustadz Syarif bahwa, dalam pengajaran akhlaq ada dua nilai yang dikenalkan kepada anak-anak para muallaf, yakni akhlaq tercela dan akhlaq terpuji. Dalam hal ini tentu nilai yang diinternalisasikan dalam diri anak didik adalah nilai yang berkaitan dengan akhlak terpuji (Akblakul Kharimah). Yaitu membangun nilai akhlaq yang berhubungan dengan Allah, mentauhidkan Allah, taqwa, berdoa, dan tawakkal. ${ }^{14}$

Artinya seorang anak selalu menempati janjinya kepada Allah yaitu melaksanakan ibadah sholat berjamaah, sebab di lingkungan pondok pesantren anakanak kristen dan Islam masih hidup berdampingan dan selalu bermain bersama, dan ketika seorang anak tidak ditekan pada nilai islam maka seiring waktu anak-anak

\footnotetext{
12 Sarif (Pembina) wawancara tanggal, 18 oktober 2016

${ }^{13}$ Edy Muliadin (Pembina ) wawancara tanggal, 18 oktober 2016

${ }^{14}$ Ibid
} 
tersebut tidak memahami islam dengan baik sebab di lingkungan kesehariannya sering terdengar lontaran kata-kata yang jorok, biasanya tidak bisa mengenal atau menggunakan kata yang sopan ketika memanggil yang lebih dewasa atau orang tuanya ini memperlihatkan akhlak tercela. hasil pengamatan peneliti adanya proses internalisasi nilai-nilai keislaman oleh pondok pesantren Umar Bin Abdul Azis mampu memanimalisir kebiasaan tersebut terutama ketika adzan berkumandang anak-anak para muallaf meninggalkan aktifitasnya dan melakukan shalat berjamaah bagi yang dekat dengan masjid, dan melanjutkan kegiatan di masjid sebagai tempat pusat kegiatan pondok pesantren ketika baada asyar dan bagi anak-anak yang tidak berjamaah di masjid berbondong-bondong di antar oleh orang tuanya.

Lebih lanjut ustadz Nehrun memaparkan, anak-anak pondok pesantren di programkan untuk mempelajari tentang al-Qur'an dari dasar, seperti pengenalan tentang huruf hija'iyah, belajar iqra, ilmu tajwid dan menyambung huruf dan ada juga yang menghafal. Hal ini yang mendasari pondok pesantren yang merupakan sebuah proses yang terpenting dalam penanaman nilai Qur'ani terhadap anak-anak mengingat orang tua di rumah tidak bisa mengajarkan baca al-Qur'an dengan baik dan benar atas dasar keterbatasannya terhadap kemampuan membaca Al-Qur'an, maka dengan sendirinya nilai-nilai keimanan itu akan timbul mencintai Allah ${ }^{15}$.

Juga Seperti yang diungkapkan oleh salah satu tokoh agama bapak $\mathrm{H}$. Syamsudin yang merupakan seorang muallaf, bahwa peran pondok pesantren sangatlah penting untuk menginternalisasikan nilai-nilai keislaman

"sebab dulu semenjak saya masuk islam kesulitan untuk mencari tempat anakanak untuk mempelajari tentang keislaman yang kaffah yang bisa mencerminkan dirinya memiliki perilaku yang bernilai-nilai islam, tapi anak saya yang berikutnya memiliki tempat untuk mempelajari keislaman dengan hadirnya pondok pesantren pada tahun 2007 tersebut". ${ }^{16}$

Jadi dari hasil uraian di atas sangatlah jelas bahwa yang mendasar untuk melakukan sebuah internalisasi nilai-nilai keislaman pada anak-anak muallaf yaitu sikon kehidupan dan pengajaran pendidikan oleh orang tua sebagai pendidikan pertama di rumah sangatlah tidak memungkinkan karna orang tua sebagai muallaf

${ }^{15}$ Nehrun Wawancara Tanggal, 20 Oktober 2016

${ }^{16}$ Syamsudin, (tokoh agama) wawancara tanggal, 20 oktober 2016 
pun masih membutuhkan pemahaman tentang keislaman sebagai keyakinan yang baru ia tempuh dan pahami untuk bisa meyakinkan lagi atas ketuhanannya dan mengenai sholat pun orang tua masih lupa waktu untuk membimbing anaknya, maka dengan adanya ketentuan dan kewajiban dengan metode paraf shalat dan hukuan menghafal sangat membantu anak-anak untuk mengingat shalat.

Pola yang dibangun di pondok pesantren sangatlah bermasyarakat dengan tidak adanya pembelajaran atau kajian terselubung yang menghadirkan kecurigaan umat beragama lain, dibandingkan awal berdirinya pondok masih menggunakan konsep idealis para pembinanya dan menurut pak Muhtar pada saat itu berkembang dan sangat bagus dan sangat berkembang pemahamannya karna sudah ada beberapa periode generasi yang dihasilkan. Akan tetapi pasca peledakan bom di salah satu pondok pesantren yang ada di Bima, sehingga hadir rumor di masyarakat bahwa pondok melahirkan generasi yang sifatnya radikal dabn tidak berakhlaq. ${ }^{17}$ Lebih

Sesuai dengan pendapat Ustadz Salman, bahwa mulai saat itulah pondok Umar Bin Abdul Azis mulai mengalami perubahan pembinaan yang bersifat toleransi dan pondok bermasyarakat, akan tetapi kelemahannya para pembina yang biasa menerima konsep pondok demikian tidak bertahan, sehingga pembina pondok pesantren Umar bin Abdul Azis sangatlah terbatas, akan tetapi sudah mampu menyatukan persepsi di tengah masyarakat dan bisa diterima oleh kalangan umat beragama di lingkunganya. Dengan lebih mensoialisasikan bahwa islam damai dan berakhlaq, maka lebih pada membina perilaku, tuturkata dan disiplinnya anak-anak ${ }^{18}$

Jadi pola pembinaan yang dilakukan oleh pondok pesantren sangatlah sesuai, ini dapat dikaji dan dilihat dari perkembangan anak-anak yang menjadikan masjid pondok pesantren sebagai tempat untuk menerima pembelajaran tentang keislaman dan para orang tuapun bersepakat dengan adanya proses internalisasi nilai-nilai keislaman terhadap anak-anak muallaf berdampak pada orang tua.

Namun Tidak sebatas yang diuraikan di atas mengenai penanaman nilai-nilai pada anak-anak para muallaf, yang dilakukan oleh pondok pesatren Umar Bin Abdul Azis juga melakukan penanaman pada pranata kehidupan yaitu pada penanaman nilai Ilahiyah dan nilai Insaniyah yaitu:

${ }^{17}$ Muhtar wawancara tanggal 28 oktober 2016

18 Efendi (Pimpinan Pondok) wawancara tanggal 28 oktober 2016 


\section{Nila Ilahiyah}

Nilai ilahiyah merupakan sebuah supstansi nilai yang berpedoman pada hukum yang benar dan jelas tidak hanya diucapkan oleh lisan akan tetapi mampu dirasakan dengan iman, jika manusia mampu merinci apa saja wujud nyata atau substansi ketuhanan maka akan di dapatkan nilai-nilai keagamaan pribadi yang sangat penting yang harus ditanamkan pada setiap pribadi anak. Sebagaimana yang diungkapkan oleh Ustazah Fitri maka secara psikologis atau mental anak akan mampu menggambarkan kebesaran dan kekuasaan tuhan dalam dadanya dengan keimanan dan ketakwaan kepada Allah, kemudian mampu menunjukan sikap yang penuh kepercayaan kepada Allah sebagai tuhan yang menciptakannya. ${ }^{19}$

Demikian juga disampaikan oleh Ustaz Nehrun bahwa, sikap taat dan patuh kepada Allah akan menghadirkan rasa syukur dari segala layanan nikmat yang telah dirasakan dengan imannya. ${ }^{20}$

Dari uraian di atas dapat disimpulkan bahwa ketika segalanya dipandang dan berpedoman pada Al-Qur'an maka dengan sedirinya iman selalu memperkuat mental anak bahwa senantiasa Allah selalu hadir bersamanya, dan bahkan sadar Allah selalu mengawasinya di manapun manusia berada, selalu menyerahkan diri kepadaNya, bersukur atas segala nikmat dan karunia yang telah diberikan dan bahkan manpu bersikap tabah menghadapi siklus hidupnya yang silih berganti atara kesulitan dan kemudahan bahwa semua itu berasal dari Allah semata.sedangkan dari sisi. Sedangkan

\section{Nilai Insaniyah}

Sebagaimana yang telah diuangkapkan oleh Ustaz Sarif bahwa, nilai Insaniyah merupakan nilai yang perlu juga ditanamkan kepada anak-anak para muallaf agar mampu menggunakan akal sehat, hati nurani yang berpijak pada idealis hidup yang dimiliki sebagai kekuatan untuk menghadirkan budi luhur dalam kepribadian anakanak tersebut, dengan kepribadian yang kuat, agar tidak gampang menjarah segala hal yang buruk di lingkungannya dan mampu membangun komunikasi dalam kehidupan sosial secara cinta kasih kepada sesama tanpa saling mengklaim satu sama lainnya terutama saling menyalahkan seimannya. ${ }^{21}$

\footnotetext{
${ }^{19}$ Fitri (Pembina Putri) wawancara Tanggal 20 November 2016

${ }^{20}$ Nehrun( Pembina) wawancara tanggal, 6 November 2016

${ }^{21}$ Syarif (Pembina) wawancara Tanggal 10 November 2016
} 
Sejalan dengan yang diungkapkan oleh pak Ridwa, bahwa nilai Insaniyah merupakan kekuatan untuk mengikat ukwah sesama dan memperkokoh silaturahmi dan kehidupan sosial, sebab dusun Tolonggeru merupakan dusun yang sangat perlu dibangun tetang kehidupan sosial karena memiliki beragam umat beragama yang masih pertalian keturunan darah, agar anak-anak para muallaf mampu membangun keharmonisan di tengah umat beragama, dengan penuh rasa tabah, sabar dan ikhlas menjalani kehidupannya. ${ }^{22}$

Dari uraian di atas bahwa nilai Insaniyah sangat penting ditanamkan kepada anak-anak para muallaf mengigat lingkungan Tolonggeru merupakan lingkungan yang memiliki beberapa agama dan konsep tuhan yang berbeda, sedangkan saling bertalian kekeluargaan, maka dengan nilai inilah dapat membangun cinta kedamain dan keharmonisan umat dan secara fenomenal keharmonisan ini telah berlaku selama ini tanpa ada perpecahan satu rumpun keluarga walaupun satu rumah memiliki penghuni tiga agama.

Sebagaimana telah digambarkan pada diagram Proses internalisasi nilai-nilai keislaman pada anak-anak para muallaf di bawah ini sebagai jalur pelaksanaan internalisasi nilai-nilai keislaman pada anak-anak para muallaf di pondok pesatren Umar Bin Abdul Azis:

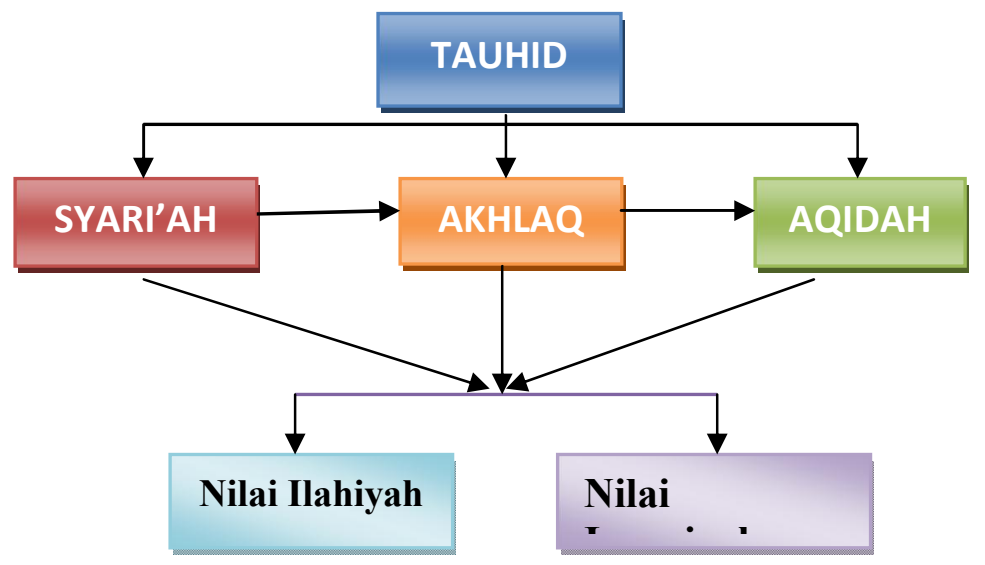

\section{Kedua: Strategi Internalisasi Nilai-Nilai Keislaman Pada Anak-Anak Para Muallaf}

22 Ridwan (tokoh masyarakat) Wawancara Tanggal 11 November 2016 
Dalam menumbuhkembangkan potensi nilai-nilai keislaman, ada beberapa strategi ataupun metode yang dilakukan oleh pembina pondok pesatren Umar Bin Abdu Azis. Strategi internalisasi nilai-nilai keislaman yang dilakukan yaitu melakukan sosialisai dengan cara memperlihatkan perilaku yang baik dan santun yang bisa ditiru atau dicontohi oleh anak-anak para Muallaf di antaranya yaitu:

\section{Pertama: Strategi Keteladanan.}

Sebagaimana yang diungkapkan oleh pak Muhtar, SE. Bahwa keteladanan merupakan sikap yang tepat ditunjukan di hadapan anak-anak di dalam lingkungan pondok atau di lingkungan masyarakat, berkaitan dengan keteladanan maka akan cepat menarik perhatian atau simpatik para anak-anak untuk mepelajari nilai-nilai keislaman, dan tidak mungkin anak-anak mau mempelajari tentang nilai-nilai keislaman jika keteladan tidak ditemukan pada diri pembinanya, sebab dusun Tolonggeru sangat sensitif dengan proses yang bersifat menekan kehendak, karena berada dalam kehidupana mayoritas, kemudian pondok pesantren dikelilingi oleh umat-umat beragama Kristen. Maka, di sini strategi keteladan sebagai pusat perhatian bagi anak-anak. dan hal ini telah dipraktekkan sejak zaman Rasulullah SAW, sebagaimana Rasulullah melakukan dakwah di tengah umat yang beda keyakinan dengan mengedepankan keteladannya. ${ }^{23}$

Jadi keteladanan ini memiliki nilai yang penting dalam melakukan internalisasi nilai-nilai keislaman kepada siapapun terutama pada anak-anak, karena memperkenalkan perilaku yang baik melalui keteladanan sama halnya memahami sistem nilai dalam bentuk nyata. Dan bisa memberikan arti dan makna bahwasannya apa yang dilakukannya itu benar adanya bukan dibuat-buat.

"Sebagaimana yang di tegaskan oleh pak Edy Muliadin, bahwa dengan keteladanan sama halnya memberi contoh-contoh kongkrit pada anak-anak. Dalam memberikan contoh-contoh ini sangat ditekankan karena tingkah laku seorang pendidik atau pembina mendapatkan pengamatan khusus dari para ana-anak. Seperti halnya ketika waktu azan berkumandang berarti menyegerakan diri menuju masjid sebagai tanda rasa taqwa dan pentingnya mendekatkan diri kepada Allah lewat melaksanakan shalat berjamaah di masjid. ${ }^{24}$

${ }^{23}$ Pak. Muhtar,SE, wawancara tanggal, 11 noveber 2016

${ }^{24}$ Edy Muliaddin, wawancara tanggal, 11 noveber 2016 
"Selaras dengan apa yang disampaikan oleh Ustaz Nehrun bahwa, shalat berjama'ah di masjid merupakan sebuah ikatan untuk membangun silaturahmi antara sesama muslim yang mengaku taat kepada Allah dan hal ini menunjukan keteladan yang luar biasa bagi anak-anak. Sekaligus sebagai wadah pelaksanaan kongrit untuk membiasakan anak-anak melaksanakan sholat tepat waktu di mesjid dan sebagai upaya untuk menghindari rasa malas dalam dirinya" 25

Serasa denngan apa yang di sampaikan oleh Ustaz Efendi bahwa Melalui strategi keteladanan ini memberikan banyak hal ketika berada di lingkungan pendidikan sebagi pelajaran langsung yang diamati oleh anak-anak yang dididik, dan bahkan sangat efektif karena dapat ditiru atau diikuti langsung oleh anak-anak. Sebab seorang anak yang kebanyakan hanya bisa meniru dan tidak banyak anak bisa memberikan porsi atau memilih dan memilah kesalahan dan kebenaran di lingkungannya walaupun telah disampaikan atau diajari secara teori atau ceramah yang berulang-ulang. ${ }^{26}$

Jadi upaya ini sangatlah perlu ketika memberikan atau melakukan internalisasi nilai-nilai keislaman kemudian harus dicontohi dengan perilaku dan tindakan keteladan yang nyata di lingkungan sebagai upaya mensosialisasi perilaku keislaman pada anak-anak dan masayarakat sekitarnya, sehingga di sisi ini akan tercipta nilai-nilai moral religius seperti ketaqwaan, kejujuran, keikhlasan, dan tanggungjawab yang ditanamkan kepada anak didik. Dan perilaku ini sangat dibutuhkan terkait pondok pesatren yang berada di tengah umat Kristen agar tidak dibenturkan dengan kalimat islam faham radikal dan kekerasan.

Sebagaimana pak Ridwan kembali menegaskan bahwa sebaiknya Islam memperlihatkan perilaku yang ramah dan tak menekan atau menakutkan bagi umat lain yang ada di sekitar pondok, sebab hal ini akan berpengaruh pada jiwa anak-anak para muallaf untuk mempelajari tentang keislaman. ${ }^{27}$

Jadi strategi utama yang dilakukan oleh pondok pesatren yaitu menunjukan perilaku keteladan sebagai upaya mensosialisasikan perilaku keislaman yang bernilai baik dihadapan anak-anak para muallaf yang dididik di lingkungan pondok.

\footnotetext{
${ }^{25}$ Nehrun, wawancara tanggal, 10 noveber 2016

${ }^{26}$ Efendi (Pimpinan Ponpes) wawancara Tanggal 10 November 2016

${ }^{27}$ Ridwan (Tokoh Masyarakat) wawancara Tanggal 11 November 2016
} 


\section{Kedua: Strategi Latihan dan Pembiasaan}

Latihan dan pembiasaan adalah cara yang dilakukan agar terbiasa dan dapat dilakukan berulang-ulang sehingga menjadi mudah untuk dikerjakan atau dilakukan.

Sebagaimana yang diungkapkan oleh pak Yusuf bahwa ketika seorang anak didik dengan melakukan secara berulang-ulang maka dengan sendirinya nilai-nilai apapun bisa terendap di dalam ingatan atau perilaku anak-anak terutama nilai-nilai keislaman. Dan pembiasaan itu telah dilakukan oleh pondok pesatren, anak-anak diajarkan untuk mengucapkan salam ketika masuk rumah, bertemu dengan orang di jalan, atau guru di sekolah, bahkan ketika anak lupa membawa salam maka pembina menegurnya dengan salam terlebih dahulu ketika bertemu dengan anak-anak sebagai upaya untuk mengigatkan anak-anak terhadap perilaku bertemu dengan orang-orang seiman dan seaqidah sehingga keterbiasan ini selalu berulang-ulang. ${ }^{28}$

Sejalan dengan yang di sampaikan oleh pak Edy Muliadin, Pembiasaanpembiasaan tersebut diantaranya juga dengan akblaqul karimah, seperti mengucapkan salam; membaca basmalah pada saat akan mengerjakan sesuatu; membaca hamdalah pada saat mendapatkan kenikmatan dan setelah mengerjakan sesuatu; ${ }^{29}$ menghormati orang lain; memberi shodaqoh; memelihara kebersihan. Adapun doa-doa yang diajarkan: doa sebelum makan dan sesudahnya; doa keluar dan masuk rumah; doa mau tidur dan bangun tidur; doa untuk orang tua; doa keselamatan di dunia dan akhirat.

Apabila hal ini sudah menjadi kebiasaan, maka anak didik akan tetap melaksanakannya walaupun dia sudah tidak lagi ada dalam pondok pesantren. Dari sini terlihat bahwa kebiasaan baik yang dilakukan oleh seorang pendidik akan membawa dampak yang baik pula pada diri anak didiknya.

Sebagaimana yang ditegaskan oleh pak Muhtar, SE, strategi pembiasan ini sangat efektif dilakukan oleh para pembina pondok pesatren Umar Bin Abdul Azis kepada anak didik yang masih membutuhkan peniruan terhadap perilaku, karena mereka belum terpengaruh oleh budaya-budaya yang negatif dan arus globalisasi yang lebih buruk. Hanya saja memiliki keterbatasan pemahaman Islam karena guru pertama anak adalah orang tua, namun orang tua mereka adalah para muallaf

${ }^{28}$ Yusuf (Tokoh Pendidik) wawancara Tanggal 10 November 2016

${ }^{29}$ Edy Muliadin, (Tokoh Pendidik) wawancara Tanggal 25 Oktober 2016 
sehingga pelajaran agama dan keteladan Islam dari orang tuanya masih sangat minim. ${ }^{30}$

Jadi Apabila anak didik dibiasakan dengan akhlak dan sikap yang baik maka akan tercermin dalam kehidupan sehari-harinya pada pergaulan yang islami pula, kalau mereka tinggal di lingkungan yang baik maka sangat mudah berinteraksi dengan pembiasaan lingkungan yang mencerminkan nilai-nilai keislaman, dan perilaku ini sangat dibutuhkan di lingkungan pondok pesatren yang mayoritas Kristen. Sehingga yang berkeyakinan lain dari Islam tidak turut curiga akan pendidikan anak-anak para muallaf di lingkungan pondok pesatren akan watak dan perilakunnya.

\section{Ketiga: Strategi Pemberian Nasehat}

Starategi ini dilakukan sebagaimana yang diungkapkan oleh Ustazah Fitri bahwa sebagai peringatan atas kebaikan dan kebenaran, dengan jalan apa saja yang dapat menyentuh hati dan membangkitkannya untuk mengamalkan. Artinya menyampaiakan kepada anak-anak tentang kebenaran yang harus dilakukan oleh seseorang, misalnya: tentang sopan santun terhadap orang tua, terhadap seorang kakak atau adik, terhadap guru dan bahkan terhadap orang lain. Nasehat ini selalu dilakukan akhir dari pelajaran, misalnya "ketika saya mengajarkan Iqra atau membaca Al-Qur'an rutin pada setiap sorenya dari akhir pelajaran selalu memberikan nasehat berupa saling bertutur kata yang sopan dan santun serta selalu patuh pada orang tua. ${ }^{31}$

Sejalan dengan apa yang dikemukakan oleh Uztaz Nehrun bahwa, nasehat merupakan salah satu motivasi untuk melakukan kebaikan, sebab nasehat merupakan cara untuk meneguhkan hati anak-anak dalam berbuat baik terhadap sesamanya, misalnya yang sering dilakukan adalah anak-anak dinasehati untuk tidak saling menggunjing terhadap anak-anak agama lain sebagi teman bermain di lingkungan luar pondok, atau mencaci tentang ketuhanan yang diimani oleh anak-anak agama lain yang ada di lingkungan pondok, karena hal ini merupakan hal yang paling sensitif akan kenyaman pondok di tengah umat Kristen dan akan menimbulkan kebencian di tengah keragaman umat beragama. ${ }^{32}$

\footnotetext{
${ }^{30}$ Muhtar, wawancara Tanggal 10 November 2016

${ }^{31}$ Fitri (Pembina santri Putri) wawancara Tanggal 10 Oktober 2016

32 Nehrun, wawancara tanggal, 10 noveber 2016
} 
Uraian yang dikemukakan di atas memberikan sebuah barometer yang kuat bahwa pemberian nasehat merupakan senjata yang tepat yang diakukan oleh pondok pesatren agar anak-anak dapat memahami arti dari keisalaman yang sebenarnya akan menjadi tujuan hidup bersama tanpa ada saling menyakiti dan tahu batas-batas mana yang harus dilakukan.

Seprti yang diungkapkan oleh Ustaz Efendi, lewat nasehat juga dapat menyampaikan peringatan tentang dosa yang muncul dari adanya larangan, bagi dirinya dan orang lain. Sehingga anak-anak memiliki tolak ukur dalam setiap periakunya yang harus dihindari atau di sadari ketika melakukan sesuatu yang dilarang atau yang disuruh. Misalnya ketika tidak mendengar panggilan orang tua atau purapura tidak mendengarnya maka itu akan termasuk dosa terhadap orang tua. ${ }^{33}$

Dari segi metode dan strategi yang digunakan, internalisasi nilai-nilai keislaman pada anak-anak para muallaf juga harus dilakukan secara komprehensif. Strategi ini agar dapat menjadi teladan bagi anak didiknya dalam bertindak dan bertutur kata. Anak-anak para muallaf perlu diasah kemampuan keislamannya agar menjadi generasi muda yang mandiri dan bertanggungjawab. Selain itu, perlu membekali anak-anak para muallaf dengan nilai keislaman agar kelaknya menjadi generasi yang dapat diteladani baik di lingkungan akademik dan lingkungan sosial.

Penulis mengamati keadaan Pondok Pesantren Umar Bin Abdul Azis bahwa anak-anak para muallaf yang dibina kebanyakan tidak ada yang di asramakan, tetapi melakukan pesantren masyarakat sehingga anak-anak tetap kembali ke rumah selepas pembelajaran agama di pondok.

Sebagaimana yang dijelaskan oleh Ustaz Syarif bahwa anak-anak kembali ke rumah dengan bertujuan agar orang tua dapat membantu mengawasi perkembangan anaknya dan ada motivasi bagi orang tua untuk mengingatkan anaknya akan waktu sholat, ada kegiatan pondok dan segala aktifitas yang berkaitan dengan keagamaan, dan bukan sebatas itu, ada upaya untuk mempermudah kegiatan rutin pengajian keislaman di masjid pondok dengan mudah mengundang orang tuanya lewat anakanak yang mereka percayakan untuk belajar keislaman di Pondok Pesatren Umar Bin Abdul Azis. ${ }^{34}$

${ }^{33}$ Efendi (Pimpinan pondok) wawancara Tanggal 10 November 2016

34 Syarif (Pembina) wawancara tanggal 10 Oktober 2016 
Mengenai penjelasan tersebut membangun sebuah sosialisasi nilai kepercayaan terhadap anak-anaknya sehingga orang tua termotivasi untuk mengikuti kegiatan keagamaan ketika diajak oleh anak-anaknya, menyangkut masalah ini di lingkungan pondok pesatren merupakan lingkungan muallaf, artinya muslim yang diyakini kebanyakan dusun Tolonggeru karena terjadinya konfersi agama atau pindah keyakinan.

Sejalan dengan yang disampaikan oleh Ustaz Nehrun bahwa pondok pesantren melakukan pembinaan dengan cara terbuka di tengah masyarakat selain untuk menghindari karena adanya rumor bahwa pondok pesantren mendidik kekerasan dan perilaku gerakan teroris juga melakukan sosialisasi Islam yang ramah damai dan nyaman di tengah keberagaman umat di dusun tolonggeru. ${ }^{35}$

Jadi Internalisasi nilai-nilai keislaman pada nanak-anak para muallaf tidak terlepas dari membangun komunikasi yang baik tentang agama Islam di tengah umat beragama di dusun Tolonggeru sebagai kode atau tanda bahwa Islam adalah agama yang ramah, nyaman dan terbuka untuk membangun kehidupan bersosial. Maka dengan sentuhan ini membuat kehidupan umat beragama di dusun Tolonggeru saling memahami dan dengan adanya pondok pesatren di tengah-tengah mayoritas tidak ada kecurigaan dan saling menyinggung antar agama, ketuhanan dan bahkan saling merangkul dan saling menjaga keharmonisan umat beragama.

Adapun skema strategi internalisasi nilai-nilai keislaman pada anak-anak para muallaf yaitu:

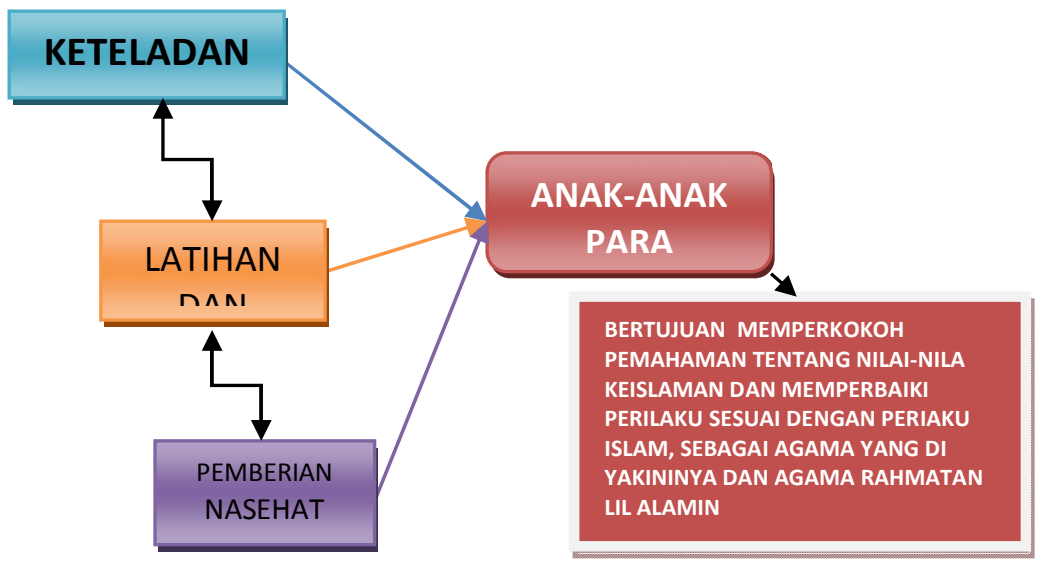

${ }^{35}$ Nehrun,(Pembina) wawancara tanggal, 10 Oktober 2016 


\section{Faktor Pendukung dan Penghambat dalam Internalisasi Nilai-nilai} Keislaman pada Anak-anak Para Muallaf.

Dalam pelaksanaan kegiatan menginternalisasikan nila-nilai keislaman pada anak-anak para muallaf ada beberapa faktor pendukung dan penghambat yang di temukan.

\section{Faktor yang mendukung.}

\section{Masyarakat sekitar memiliki kesadaran tinggi atas hak dan kewajiban} sebagai orang tua harus mendidik anak-anaknya.

Dalam proses menginternalisasi nilai-nilai keislaman yang dilakukan oleh pondok pesantren Umar Bin Abdul Azis mendapatkan dukungan dari para masyarakat muallaf agar anak-anaknya bisa dan paham tentang keislaman. Seperti yang diungkapkan oleh salah satu muallaf ibu Maryanti, bahwa dengan adanya pondok di tengah dusun ini memberikan kemudahan bagi anak-anak untuk bisa menimba ilmu keislaman terutama belajar mengaji. ${ }^{36}$

Demikian juga yang disampaikan oleh ibu rumah tangga ibu Misnah, bahwa dengan adanya pondok yang dekat, maka anak-anaknya bisa mengaji dan mau melaksanakan sholat berjamaah di masjid, kalau tidak ada pondok mungkin sulit untuk anak-anak bisa mengaji, sedangkan kami ini seorang muallaf yang pada dasarnya tidak bisa mengaji, maka kami mengingatkan setiap kegiatan dan jadwal mengaji bagi anak-anak kami. ${ }^{37}$

Uraian dari pendapat di atas menggambarkan bahwa kehadiran pondok pesantren sebagai wadah untuk menginternalisasikan nilai-nilai keislaman pada anakanak sangatlah didukung karena berkaitan dengan keberlanjutan keyakinan anaknya itu harus tahu tentang kebenaran islam dan nilai-nilai yang terkandung dalam agama islam maka akan terlihat cerminan aqidah dan akhlak pada anak dalam arti anakanaknya mau menuruti dan mau belajar tentang islam lebih dalam lagi.

\section{Masyarakat dan tokoh umat beragama menerima keberadaan pondok} pesantren dengan positif.

Berkenaan dengan hal ini, tokoh agama memandang sangat obyektif terkait pondok pesantren yang terbangun di tengah keberagaman umat, dan dengan adanya

\footnotetext{
36 Yanti, wawancara tanggal 19 September 2016

${ }^{37}$ Misnah wawancara tanggal 18 September 2016
} 
pondok pesantren tersebut tidak memecah belah umat akan tetapi menambah ikatan sosialisasi kebersamaan yang tinggi, dan bagi Mullaf ada tempat untuk mengkaji keislaman lebih dalam lagi.

Sebagaimana yang diungkapkan oleh salah satu tokoh agama sekaligus khatib di masjid Umar Bin Abdul Azis bapak H. Muhammad Saleh, bahwa dengan adanya pondok pesantren pengajian di bulan puasa dilakukan secara intens dan itu menambah ukhwah islamiah, silaturahmi dan menambah pemahaman tentang islam, jadi bahkan untuk melakukan internalisasi nilai-nilai keislaman pada anak-anakpun lebih baik karena saling bergandengan tangan antara orang tua dan anak-anak sewaktu mengikuti pengajian. ${ }^{38}$

Berkaitan dengan penjelasan di atas penulis menyimpulkan bahwa faktor yang mendukung dengan hadirnya pondok pesantren sebagai tempat atau wadah untuk memberikan gairah dalam membangun semangat untuk mempelajari tentang keislaman, baik nilai-nilai keislaman yang ditanamkan kepada anak-anak maupun hukum islam sebagai pegangan para orang tuanya.

\section{Sedamngkan penghambatnya.}

\section{a. Keterbatasan Pembina}

Pondok pesantren sangat kekurangan pembina yang bisa menetap di dalam pondok pesantren yang rutin untuk mengatur santrinya. Bahkan kegiatan pondokpun sering macet ketika dari beberapa pembina tersebut ada kesibukan di luar. Sebagaimana yang diungkapkan oleh Ustadz Nehrun bahwa "sangat sulit mendapatkan pembina yang mau rutin berada di pondok disebabkan oleh jauhnya jarak antara desa pusat dengan dusun tenpat perpondokan, inilah yang mengakibatkan kendala untuk mendapatkan pembina, jika ada pembina yang siap untuk rutin maka akan bermasalah pada operasionalnya". ${ }^{39}$

Demikian juga pendapat Pak Yusuf selaku tokoh masyarakat, seharusnya pemateri pengajian atau guru ngaji harus ada ustadz lain juga yang akan memberikan materi agar tidak satu atau dua orang itu saja yang akan memberikan materi ketika keduanya berhalangan maka menimbulkan banyak alasan bagi anak-anak untuk tidak

${ }_{38}^{38}$ Muhammad Saleh (tokoh agama/hatib masjid) wawancara tangga, 1 November 2016

${ }^{39}$ Nehrun wawancara tangga, 20 Oktober 2016 
hadir hari berikutnya, ini kemudian berdampak pada hilangnya motivasi seorang anak dan tidak mencerminkan nilai-nilai keislaman itu timbul dari dalam diri anak. ${ }^{40}$

\section{b. Kurang Terarahnya Konsep Pembelajaran Pondok}

Corak pelaksanaan kegiatan pondok masih belum terarah sesuai dengan visi dan misi. Seperti yang disampaikan oleh pak Muhtar pada awalnya pondok ini merupakan pondok Tahfidz akan tetapi dengan beriringan waktu dan semakin lemahnya pembina sehingga pondok ini hanya menjalankan sesuai dengan keadaan yang ada juga bertahan dengan kebiasaan yang ada, yaitu melakukan sebagaimana umumnya pondok yang baru dirintis dan belum memadai segala kebutuhannya. Sehingga berjalan pada konsep yang normatif dan sesuai dengan kebutuhan anakanak dan masyarakat di sekitarnya. ${ }^{41}$

\section{c. Keterbatasan Sumber Daya Alam}

Selama ini pondok mengalami keterbatasan sumber daya alam, inilah yang membuat susah diasramakannya semua santri pondok, seperti keterbatasan air, pondok pesantren memiliki keterbatasan air bertahun-tahun karena pondok terbangun di dusun yang gersang dan bebatuan tanpa ada mata air di sekitarnya. Sebagaimana yang disampaikan oleh pak Yusuf, seandainya ada aliran air yang memadai maka pondok akan kondusif dan layak dihuni lebih banyak santri. ${ }^{42}$

Jadi penulis dapat menarik kesimpulan bahwa hambatan yang terbesar terletak pada fasilitas pembina yang tidak memadai sehingga menjadi hambatan terbesar jalannya internalisasi nilai-nilai keislaman pada anak-anak para muallaf, dan sulit berjalannya program pondok yang telah dibangun dan dikonsepkan sesuai visi dan misi yang telah ada jutga sekilasa permasalahan penghambatnya juga terletak pasa sarana bdan prasarana.

\section{PEMBAHASAN}

Proses Internalisasi nilai-nilai keislaman pada anak-anak para muallaf adalah upaya menanamkan nilai-nilai keislaman yang sifat qur'ani dan hal itu menjadikan pembiasaan di lingkungan masyarakat yang mayoritas Kristen. Adapun proses pembiasaan tersebut adalah dengan menciptakan suasana religius di lingkungan

\footnotetext{
${ }^{40}$ Yusuf (tokoh masyarakat) wawancara tangga, 28 Oktober 2018

${ }^{41}$ Muhtar wawancara Tanggal, 27 Oktober 2016

42 Yusuf wawancara Tanggal, 23 Oktober 2016
} 
Pondok Pesantren Umar Bin Abdul Azis, kegiatan-kegiatan keagamaan dan praktikpraktik keagamaan yang dilaksanakan secara terprogram dan rutin (pembiasaan) diharapkan dapat mentransformasikan dan menginternalisasikan nilai-nilai keislaman pada anak-anak para muallaf, Nilai penting yang ditanamkan yaitu keyakinan sebagaimana dalam pandangan Darajat, dkk memberikan pengertian bahwa nilai adalah suatu perangkat keyakinan ataupun perasaan yang diyakini sebagai suatu identitas yang memberikan corak yang khusus kepada pola pemikiran, perasaan, keterikatan, maupun perilaku. ${ }^{43}$

Maka dengan keyakinan yang dimilikinya akan mempermudah proses internalisasi nilai-nilai keislaman seperti latihan-latihan beragama yang menyangkut seperti ibadah shalat berjamae ah, puasa, zakat, doa-doa dan menghafal surat pendek, harus dibiasakan sejak kecil agar nantinya bisa merasakan manisnya beribadah. Pada dasarnya apabila sejak dini anak sudah beriman kepada Allah SWT, takut kepadaNya, meminta tolong dan berserah diri kepada-Nya, niscaya dia akan mempunyai kemampuan fitri dan tanggapan naluri untuk menerima setiap keutamaan dan kemuliaan, dan akan terbiasa dengan akhlaq mulia. ${ }^{44}$

Selanjutnya Muhammad Said menjelaskan bahwa inti refleksi perwujudan ajaran-ajaran Islam yaitu ketuhanan atau tauhid. Dengan keyakinan inilah, setiap perbuatan harus dikembalikan pada inti ajaran keislaman, karena jika tidak demikian maka itu adalah kosong. ${ }^{45}$ Untuk menghindari itu semua, ada beberapa pokok pelaksanaan dalam menginternalisasikan nilai-nilai keislaman pada anak-anak para muallaf, berkaitan dengan keterbatasan pemahaman agama bagi orang tua yang melakukan konvrensi agama namun tidak dapat mendidik anak-anaknya secara langsung di dalam lingkugan rumahnya sehingga pondok pesantren Umar bin Abdul Azis memiliki peran penting untuk meningkatkan tingkat religiusitas terhadap anakanak para muallaf tersebut dengan berbagai macam program di dalamnya. Mengenalkan tauhid, mengenakan syari'ah, nilai aqidah, dan nilai akhlaq, pendidikan hal ini sangatlah penting akan menjadikan manusia semakin dewasa dan paham

${ }^{43}$ Darajat, dkk. Dasar-dasar Agama Islam .( Jakarta : Bulan Bintang,1984),260

44 Ulwan, Abdullah Nashih, Pedoman Pendidikan Anak dalam Islam, (Semarang: Asy-Syifa ${ }^{e e}$, 1981),169

45 Muhammad Said, Peranan Islam Dalam Penghayatan, Pengamalan dan Pengamanan Pancasila, (Jakarta: Departemen Agama RI, 1985), 43 
tentang keislaman dan berkembang secara intelektual, moral dan sosial. Selain itu, juga harus mampu melakukan transformasi nilai sebagai dasar (fondasi) terutama nilai-nilai islami. ${ }^{46}$

Dalam Islam, latihan rohani yang diperlukan manusia diberikan dalam bentuk ibadah. Semua ibadah dalam Islam baik shalat, puasa, zakat, maupun haji, bertujuan untuk membuat rohani manusia agar tetap ingat kepada Allah dan bahkan merasa senantiasa dekat padaNya. Keadaan senantiasa dekat pada Allah Yang Maha Suci dan dapat mempertajam rasa kesucian yang selanjutnya menjadi rem bagi hawa nafsunya untuk melanggar nilai-nilai moral, peraturan dan hukum yang berlaku. Dalam ibadah terjadi kontak kegiatan jasmani dan rohani. Ibadah merupakan tanggapan batin yang tertuju kepada Allah, namun dibarengi dengan amal perbuatan yang bersifat lahir, yang dilakukan oleh gerak-gerik jasmani.

Ibadah secara lahiriah dan batiniah seperti itu dapat dipahami dari aspek pembawaan hidup manusia sendiri yang bersifat dualistis yang terdiri dari dua unsur jasmani dan rohani seperti disebut di atas. Kedua unsur itu menyatu dalam diri manusia.

Maka kedua-duanya membutuhkan bimbingan nilai-nilai keislaman yang kontiyu yang terdapat dalam al-qur'an sebagai pendoman yang selalu membimbing dan membina sepanjang zaman, karena Ajaran-ajaran maupun nilai-nilai yang ada di dalam al-Qur`an bersifat abadi sampai akhir zaman, artinya bahwa kandungan alQur`an selalu relevan dengan kemajuan zaman (up to date). Selain itu, kandungan ayatayat al-Qu an berlaku untuk seluruh umat manusia atau universal. ${ }^{47}$

\section{Strategi Internalisasi Nilai-Nilai Keislaman Pada Anak-Anak Para}

\section{Muallaf di Pondok Pesantren Umar Bin Abdul azis}

Dalam melakukan internalisasi nilai-nilai keislaman pondok pesantren melakukan beberapa strategi, yaitu: strategi keteladanan, strategi latihan dan pembiasaan, serta strategi pemberian nasehat. Strategi-strategi ini merupakan strategi pilihan yang tepat yang digunakan oleh pondok pesantren Umar Bin Abdul Azis, yang berada di tengah umat beragama.

46 Agus Wibowo, Pendidikan Antikorupsi di Sekolah (Yogyakarta: Pustaka Pelajar, 2013), 35.

${ }^{47}$ Mustofa Bakir, Ringkasan Materi AIK I (UMP: Purworejo, 2012), 23. 
Strategi Keteladanan merupakan strategi yang mendasar yang digunakan untuk menarik perhatian atau simpatik para anak-anak untuk mepelajari nilai-nilai keislaman, dan tidak mungkin anak-anak mau mempelajari tentang nilai-nilai keislaman jika keteladan tidak ditemukan pada diri pembinanya, sebab dusun Tolonggeru sangat sensitif dengan proses yang bersifat menekan kehendak, karena berada dalam kehidupana mayoritas, kemudian pondok pesantren dikelilingi oleh umat-umat beragama Kristen. Maka, di sini strategi keteladan sebagai pusat perhatian bagi anak-anak. Sebagaimana yang dikemukakan oleh Supardi dan Aqila bahawa keteladanan menjadi hal yang sangat dominan dalam mendidik anak. Anak pada dasarnya akan meniru apa yang dilakukan orang-orang di sekelilingnnya. ${ }^{48}$ Maka dengan strategi ini seorang guru dapat mendekatkan diri kepada anak-anak didik, sehingga dapat mengembangkan kekuatan pendidik yang sangat penting. ${ }^{49}$

Pelaksanaan penanaman nilai-nilai keislaman pada anak usia dini banyak cara atau metode yang dapat digunakan oleh pembina. Namun sebelum memilih dan menerapkan metode yang ada perlu diketahui bahwa pembina harus memahami metode yang akan dipakai, karena ini akan berpengaruh terhadap optimal dan tidaknya keberhasilan penanaman nilai-nilai keislaman tersebut.

Kemudian strategi Latihan dan Pembiasaan. Ketika seorang anak dididik dengan cara berulang-ulang (pembiasaan) maka dengan sendirinya nilai-nilai apapun bisa terendap di dalam ingatan atau perilaku anak-anak terutama nilai-nilai keislaman. Dan pembiasaan itu telah dilakukan oleh pondok pesatren Umar Bin Abdul Azis, anak-anak diajarkan untuk mengucapkan salam sebagai wujut pelatihannya ketika masuk rumah, bertemu dengan orang di jalan, atau guru di sekolah, bahkan ketika anak lupa membawa salam maka pembina menegurnya dengan salam terlebih dahulu ketika bertemu dengan anak-anak sebagai upaya untuk mengigatkan anak-anak terhadap adab bertemu dengan orang-orang seiman dan seaqidah sehingga kebiasaan ini selalu berulang-ulang.

Sejalan dengan pendapat Ulwah bahwa hendaklah para pendidik, ayah dan ibu memusatkan perhatian pada pengajaran tentang kebaikan dan upaya

\footnotetext{
48 Supardi, dan, Aqila Smart, Ide-ide Kreatif Mendidik Anak bagi Orang Tua Sibuk, (Yogyakarta: Katahati, 2010),36

${ }^{49}$ R. Moeslichatoen, Metode Pengajaran di Taman Kanak-kanak, (Jakarta:Rineka ipta, 2004),7
} 
membiasakannya sejak ia mulai memahami realita kehidupan ini. ${ }^{50}$ Sejalan dengan pendapat Noer bahwa pembiasaan merupakan cara mendidik anak dengan penanaman proses kebiasaan. ${ }^{51}$

Jadi ketika anak-anak mampu untuk membiasakan diri pada perbuatanperbuatan yang baik sesuai dengan ajaran agama dan hukum-hukum yang berlaku maka konektifitas dirinya menjadi anak yang bertaqwa, berakhlak mulia, dan berbudi luhur.

Ada beberapa hal penting yang harus diketahui oleh para pembina dalam persoalan mengajarkan kebaikan kepada anak-anak para muallaf dan membiasakan mereka berbudi luhur, yaitu dengan cara mengikuti metode pemberian dorongan dengan kata-kata baik, santun, kasih sayang dan perlindungan. Hal ini memberikan harapan kepada anak-anak para mualaf dengan keutamaan-keutamaan jiwa, akhlak dan etika sosial baik, dan harapan besar bagi siapupun di sekitarnya terutama keluarga-keluarganya yang masih non muslim.

Starategi Pemberian Nasehat. Strategi ini dilakukan sebagaimana yang diungkapkan oleh Ustazah Fitri bahwa pembina pondok sebagai pengingat atas kebaikan dan kebenaran, dengan jalan apa saja yang dapat menyentuh hati dan membangkitkannya untuk mengamalkan. Artinya menyampaikan kepada anak-anak tentang kebenaran yang harus dilakukan oleh seseorang, misalnya: tentang sopan santun terhadap orang tua, terhadap seorang kakak atau adik, terhadap guru dan bahkan terhadap orang lain, dan nasehat ini selalu dilakukan akhir dari pelajaran, misalnya "ketika saya mengajarkan Iqra atau membaca Al-Qur'an rutin pada setiap sorenya dari akhir pelajaran selalu memberikan nasehat berupa saling bertutur kata yang sopan dan satun serta selalu patuh pada orang tua, dan hal ini menjadikan anak yang tangguh kepribadiannya terhadap kebaikan.

Selaras dengan pendapat Zainuddin bahwa, nasehat-nasehat itu diberikan kepada anak agar mendapatkan pengertian tentang perbuatan dan perilakunya seharihari, sehingga setelah ia dewasa menjadi teguh dan kuat dalam pribadinya. ${ }^{52}$

\footnotetext{
${ }^{50}$ Abdullah Nashih Ulwan, Tarbiyatul Aulad fil Islam, (Beirut: Darussalam, 1997),507

${ }^{51}$ Aly, Hery Noer, Ilmu Pendidikan Islam, (Jakarta: Logos Wacana Ilmu, 1997),184

52 Zainuddin, Seluk Beluk Pendidikan dari Al- Ghazali, (Jakarta: Bumi Aksara, 1991), 81
} 
Karena hal itu pula Al-Quran banyak mencontohkannya lewat ayat yang berupa nasehat seperti ucapan Nabi Ibrahim AS. dalam surat Al-Baqarah ayat 132:

"Dan Ibrabim telah mewasiatkan ucapan itu kepada anak-anaknya, demikian pula Ya'qub. (Ibrabim berkata): "Hai anak-anakkeu! Sesungguhnya Allah telah memilih agama ini bagimu, Maka janganlah kamu mati kecuali dalam memeluk agama Islam".

Dari pandangan ayat tersebut merupakan nasehat yang amat penting terkait dengan tauhid atau keyakinan dan kepatuhan pada seorang anak. Jadi dalam pemberian nasehat merupakan strategis yang penting bagi anak-anak dalam menyadarkan dirinya atas sesuatu hal yang salah dan yang benar terhadap keyakinannya dalam menjalani kehidupan di dunia baik di lingkungan rumah maupun di lingkungan sosial.

\section{Faktor Pendukung dan Penghabat}

Di dalam penelitian ini ada beberapa permasalahan yang ditemukan mengenai faktor pendukung dan penghambat bagi jalannya internalisasi nilai-nilai keislaman pada Pondok Pesantren Umar Bin Abdul azis yang perlu ditelaah lebih jauh.

1. Masyarakat sekitar memiliki kesadaran tinggi atas hak dan kewajiban sebagai orang tua untuk mendidik anak-anaknya.

Sehingga dalam proses menginternalisasi nilai-nilai keislaman yang dilakukan oleh pondok pesantren Umar Bin Abdul Azis mendapatkan dukungan dari para masyarakat muallaf agar anak-anaknya bisa dan paham tentang keislaman. Dengan adanya pondok di tengah masyarakat mayoritas memberikan kemudahan bagi anak-anaknya untuk bisa menimba ilmu keislaman terutama belajar AlQur'an.

2. Kehadiran pondok memberikan layanan yang baik untuk kebutuhan pembelajaran agama bagi anak-anak para muallaf,

Dengan latar belakang para orang tua muallaf yang pada dasarnya tidak bisa mengaji, selalu sangat mengingatkan setiap kegiatan dan jadwal mengaji bagi anak-anaknya sebagai partisipasinya terhadap perkembangan keislaman anak dan sangat membantu untuk memudahkan kegiatan pondok yang bersifat pondok pesatren masyarakat.

3. Masyarakat dan tokoh umat beragama menerima keberadaan pondok pesantren dengan positif. 
BerdasarkanS dengan hal ini, tokoh agama memandang sangat obyektif terkait pondok pesantren yang terbangun di tengah keberagaman umat, dan dengan adanya pondok pesantren tersebut tidak memecah belah umat akan tetapi menambah ukhwah kebersamaan sesama umat beragama

\section{Adapun Faktor Penghambat}

Dalam melakukan internalisasi nilai-nilai keislaman pada anak-anak para muallaf mengalami beberapa hambatan.

Keterbatasan Pembina, hal ini yang membuat kegitan pondokpun sering mandek, dan bahakan sangat sulit mendapatkan pembina yang mau rutin berada di pondok disebabkan oleh jauhnya jarak antara desa pusat dengan dusun tempat perpondokan. Inilah yang mengakibatkan kendala untuk mendapatkan pembina, juga keterbatasan operasionalnya.

Kurang Terarahnya Konsep Pembelajaran Pondok. Kegiatan pondok tidak terlalu konsisten dan belum ada aturan kurikulum atau cirri khas yang dibangun di dalam pondok yang memadai dalam pelaksanaan kegiatan keislaman sehingga masih terlihat renggang dari kesesuaian kegiatan pondok-pondok lainnya

Keterbatasan Sumber Daya Alam. Selama ini pondok mengalami keterbatasan sumber daya alam, inilah yang membuat susah diasramakannya semua santri pondok, seperti keterbatasan air, persoalannya pondok pesantren memiliki keterbatasan air bertahun-tahun karena pondok terbangun di dusun yang gersang dan bebatuan tanpa ada mata air di sekitarnya. Dan tidak memiliki donatur yang bisa mensuplai bantuan dan kebutuhan pondok.

Jadi permasalahan yang dialami para muallaf setelah konversi agama adalah mengikuti kegiatan ritual Islam karena mereka membutuhkan proses penyesuaian diri dengan membiasakan sholat lima waktu, berpuasa dan lain sebagainya. Dari keterangan orang tua bahwa mereka masih sering meninggalkan sholat, hal lain yang menjadi kesulitan utama adalah mempelajari Al-Quran dan hal lain yang menggunakan bahasa arab karena hal ini sangat asing sehingga membutuhkan penyesuaian diri dan mempelajarinya.

Maka internalisasi nilai-nilai keislaman pada anak-anak para muallaf perlu diwujudkan dan difasilitasi dengan keterbatasan pemahaman orang tua terhadap Islam . 


\section{Catatan Akhir}

Proses internalisasi nilai-nilai keislaman pada anak-anak para muallaf yaitu: Pertama. Penanaman Nilai Tauhid. Yaitu, menanamkan ketauhidan pada anak-anak para muallaf mengigat keterbatasan orang tuanya tentang keyakinan dan ketakwaan kepada allah SWT. Kedua, Menanamkan Nilai Syari'ah, yaitu proses penanaman yang dilakukan oleh pondok agar memiliki pedoman yang jelas dalam hidupnya sehingga mampu membedakan hal baik dan buruk selama hidupnya sebagai orang Islam dan menjadikan Al-Quran dan Sunnah Sebagai pedoman hidup. Ketiga, Menanamkan Nilai Aqidah sebagai proses penanaman yang dilakukan oleh pondok pesantren untuk untuk memperkuat bahwa Allah lah yang batuh disembah dan sebagaimanma butir rukun iman dan Islam. Kempat, Menanamkan Nilai Ahklaq Nilai ahklaq merupakan proses penanaman nilai yang dilakukan oleh pondok pesantren agar anak-anak para muallaf tersebut mampu mengikuti akhlaq rasulullah, yaitu perilaku sidiqnya, tabliqknya, amanahnya, dan fatonahnya rasulullah sehingga anakanak mullaf sebagai generasi yang berperilaku islami baik di lingkungan keluarganya maupun di masyarakat sekitar.

\section{Strategi Internalisasi Nilai-Nilai Keislaman Pada Anak-Anak Para} Muallaf yaitu: Strategi Keteladanan. Strategi ini merupakan sikap yang dapat di contohi oleh anak-anak di dalam lingkungan pondok atau di lingkungan masyarakat, sebab dusun Tolonggeru sangat sensitif dengan proses yang bersifat menekan kehendak, karena berada dalam kehidupana minoritas, Strategi Latihan dan Pembiasaan. Latihan dan pembiasaan ini adalah cara yang dilakukan agar terbiasa dalam hal yang baik dan berakhlak mulia, dan Strategi Pemberian Nasehat. Starategi ini dilakukan sebagai peringatan atas kebaikan dan kebenaran, dengan jalan apa saja yang dapat menyentuh hati dan membangkitkannya untuk mengamalkan. Artinya menyampaiakan kepada anak-anak tentang kebenaran yang harus dilakukan oleh seseorang, misalnya: tentang sopan santun terhadap orang tua, terhadap seorang kakak atau adik, terhadap guru dan bahkan terhadap orang lain.

Faktor Pendukung dan Penghambat dalam Internalisasi Nilai-nilai Keislaman pada Anak-anak Para Muallaf yaitu: Pertama, Masyarakat sekitar memiliki kesadaran tinggi atas hak dan kewajiban sebagai orang tua terutama para muallaf, dengan kesadarannya untuk mendidik anaknya tentang Islam pada pondok 
pesatren, Kedua, Masyarakat dan tokoh umat beragama menerima keberadaan pondok pesantren dengan positif. Sehingga mampu menjalin kebersamaan tanpa adanya pecah belah yang bersifat politis dan profokatif, maka keberagaman umat yang ada merasa tenang dan nyaman dalam kehidupan sosial. Ada pun hambatan Yaitu: Keterbatasan Pembina. Kurang Terarahnya Konsep Pembelajaran pondok, Keterbatasan Sumber Daya Alam serta sarana dan prsarana.

\section{Daftar Rujukan}

Agus Wibowo. Pendidikan Antikorupsi di Sekolah. Yogyakarta: Pustaka Pelajar, 2013.

Aly, Hery Noer. Ilmu Pendidikan Islam. Jakarta: Logos Wacana Ilmu, 1997.

Darajat, dkk. Dasar-dasar Agama Islam. Jakarta : Bulan Bintang, 1984.

Doni Koesoema A, Pendidikan Karakter. Jakarta: PT. Grasindo, 2007.

Hasby Ash Shiddieqy, Pedoman zakat. Jakarta PT. Bulan Bintang, 1984.

Muhammad Husain Haekal. Umar bin Khattab. Bogor : Litera Antar Nusa, 2011.

Muhammad Said. Peranan Islam Dalam Penghayatan, Pengamalan dan Pengamanan Pancasila. Jakarta: Departemen Agama RI, 1985.

Mustofa Bakir. Ringkasan Materi AIK I. UMP: Purworejo, 2012.

Ramayulis. Psikologi Agama. Jakarta: Kalam Mulia, 2002.

R. Moeslichatoen. Metode Pengajaran di Taman Kanak-kanak. Jakarta: Rineka Cipta, 2004.

Supardi, dan, Aqila Smart. Ide-ide Kreatif Mendidik Anak Bagi Orang Tua Sibuk. Yogyakarta: Katahati, 2010.

Suyoto. Pondok Pesantren Dalam Pendidikan Nasional. Diedit oleh M. Dawan Raharjo, Pesantren dan Pembaharuan. Jakarta: LP3ES, 1988.

Ulwan, Abdullah Nashih. Pedoman Pendidikan Anak dalam Islam. Semarang: Asy-Syifaee, 1981.

Ulwan, Abdullah Nashih. Tarbiyatul Aulad fil Islam. Beirut: Darussalam, 1997.

Zainuddin, Seluk Beluk Pendidikan dari Al- Ghazali. Jakarta: Bumi Aksara, 1991. 